\title{
Analysis of Sea Border Transportation in Indonesia, Case Study: Crossing Between Indonesia and Philippines (Bitung - Davao City)
}

\author{
Danny Faturachman ${ }^{1}$, Aldyn Clinton Partahi Oloan ${ }^{2}$, Fridolini $^{3}$ \\ (Received: 14 September 2021 / Revised: 22 December 2021 / Accepted: 22 December 2021)
}

\begin{abstract}
Indonesia as an archipelagic country consists of thousands of islands and has a large sea area so that the required mode of transportation is sea transportation as a means of mobility and driving national economic development. In addition, Indonesian waters serve as a liaison between cities, as well as between countries. As a border on the island of Sulawesi, the city of Bitung is a link between Indonesia and the city of Davao City in the Philippines. For all of this, security for shipping, especially at the border, is needed to support the smooth delivery of goods by using Ferry Ro/Ro ships so that sea transportation activities in general and trade and economic activities between the two countries can run smoothly because maritime safety greatly affects the continuation of development efforts.
\end{abstract}

Keywords-Bitung, Crossing between Countries, Davao City, Indonesia, Philippines.

\section{INTRODUCTION}

$\mathrm{I}$ ndonesia as an archipelagic country consists of thousands of islands and has a large sea area so that the most needed mode of transportation is sea transportation as a means of mobility and driving national economic development. Transportation is the lifeblood of the economy of the Indonesian people and nation. Transportation development activities in Indonesia, especially sea transportation are increasing. This is the impact of economic activities and socio-cultural and community activities.

In addition, Indonesian waters are not only a liaison between cities and islands but also between countries. As a border on the island of Sulawesi, the city of Bitung is a link between Indonesia and the Philippines. For all of this, security is needed, especially for shipping in the territory of Indonesia because maritime safety greatly affects the continuation of development efforts, especially marine transportation activities.

Bitung Harbor is a port located on Jalan D.S Sumolang, Bitung City, North Sulawesi. It is the largest port in North Sulawesi, which is visited by passenger ships between major cities in Indonesia. The existence of Bitung Port is one of the important factors that encourage economic growth and development in North Sulawesi, apart from the plantation, agricultural, and fishery activities.

Sea transportation plays a very important role in maritime countries such as Indonesia, whose territory is

Danny Faturachman is with Department of Marine Engineering, Darma Persada University, Jakarta. 13450, Indonesia, fdanny30@yahoo.com

Aldyn Clinton Partahi Oloan is with Department of Marine Engineering, Darma Persada University, Jakarta 13450, Indonesia, clyntonaldyn19@gmail.com

Fridolini, is with Department of English Language and Culture, Darma Persada University, Jakarta 13450, Indonesia, fivienf@gmail.com an archipelago. Regarding sea transportation, there are 3 aspects that are interrelated with each other, namely traffic and sea transportation facilities, ports, shipping safety, and security.

Law no. 7 the year 2008 concerning shipping, in general provisions it is stated that shipping safety and security is a condition of fulfilling safety and security requirements concerning waters, ports, and the maritime environment. Therefore, all parties related to shipping activities must meet the requirements that have been set. Through concrete steps, compliance with shipping safety and security regulations will realize a high level of safety and security. Therefore, it is hoped that the guarantee of safety and security in the field of sea transportation can synergize the pattern of periodic supervision of the fulfillment of the safety and security aspects that have been determined.

\section{LITERATURE REVIEW}

A. Rules in SOLAS

1) Safety measures to prevent fire for passenger ships carrying more than 36 passengers (Chapter II-2 regulation 17-24).

2) Rescue equipment for passenger ships (Chapter II regulations 27-34),

In Rule 27, it is stated:

Passenger ships used in short international voyages must be equipped with:

- Ship's davit according to the length of the ship.

- Lifeboats, minimum 2 pieces.

- A life raft sufficient to accommodate $10 \%$ of the total number of passengers.

- Shirt/life jacket according to the number of passengers plus $10 \%$

3) Passenger ship safety certificate.

Ship safety is a condition of a person or more who is protected from the threat of danger/accident. Accidents are unpredictable and unexpected events that can cause losses, while security is a safe and peaceful state. 
According to Law Number 17 of 2008 concerning Shipping, it is stated that:

a) The fulfillment of safety and security requirements affecting transportation in waterways, ports, and the maritime environment is a condition of shipping safety and security.

b) The legal status of ships, safety management and pollution prevention from ships, manning, loading lines, loading, the welfare of ship's crew and health of passengers, the legal status of ships, safety management and pollution prevention from ships, and ship security management for sailing in certain waters are all aspects of ship seaworthiness.

c) The state of a ship that meets the standards of material, construction, machinery, and electrical buildings, stability, arrangement and equipment, auxiliary equipment and radio, and ship electronics, as proven by a certificate following inspection and testing, is known as ship safety.

Furthermore, it is stated in Law Number 17 of 1985 concerning the adoption of the United Nations Convention on the Law of the Sea that each State must effectively implement its jurisdiction and supervision over ships flying its flag in the administrative, technical, and appropriate domains. As a result, each country must, in particular:

a) Except for ships that are excluded from generally accepted international norms due to their small size, keep a ship registry with names and other information on ships flying their flag.

b) Exercise jurisdiction over any ship flying its flag and its captain, officers, and crew with relation to administrative, technical, and social concerns surrounding that ship under its national legislation.

To control the safety of shipping internationally, it is regulated by the following provisions:

a) International Convention for the Safety of Live at Sea (SOLAS), 1974, as amended and this international rule concerns the following provisions:

- Construction (structure, stability, electrical engineering and installation, fire protection, fire detectors, and firefighting);

- Radio communications, the safety of navigation;

- Rescue devices, such as buoys, lifeboats, life rafts;

- Implementing rules aimed at improving shipping safety and security, such as the International Safety Management (ISM) Code and the International Ship and Port Facility Security (ISPS) Code.

b) International Convention on Standards of Training, Certification, and Watchkeeping for Seafarers, 1978 and last amended in 1995.

i. International Convention on Maritime Search and Rescue, 1979. ii. International Aeronautical and Maritime Search and Rescue Manual (IAMSAR)

\section{B. Overview of Bitung city}

Bitung City is a city in the province of North Sulawesi. This city has experienced rapid growth as a result of the presence of a seaport, which fosters development. Bitung City is in Minahasa Land's northeast corner. Bitung City is made up of two parts: a land area at the foot of Dua Saudara Mountain and an island known as Lembeh. Because many citizens of Bitung City are from the Sangir tribe, Bitung's culture is inextricably linked to that of the North Nusa region.

Bitung City is mostly an industrial city, with a strong fishing sector. According to legend, the name Bitung comes from the name of a tree (Oncosperma tigillarium syn. O. filamentosum; Nibung) that grows abundantly in Sulawesi's northern peninsula. Dotu Hermanus Sompotan, also known as Tundu'an or leader in the local language, was the first person to give the name Bitung. Dotu Hermanus Sompotan was not alone at the time; Dotu Rotti, Dotu Wullur, Dotu Ganda, Dotu Katuuk, and Dotu Lengkong were all present. The word Dotu was used to refer to an elder or a leadership title at the period, similar to how the word Datuk was used to refer to persons in Sumatra. They are known as the 6 Dotu Tumani Bitung, and they all originated from the Minahasa Tribe, Tonsea ethnicity. They opened and worked on the region to make it a decent area to live in. This new beachfront location attracted a large number of people to come and reside permanently, and Bitung's population began to rise over time. Bitung was merely a hamlet before becoming a city, led by Arklaus Sompotan, who served as the first Old Law (Lurah) of Bitung village and ruled for about 25 years. At the time, Bitung Village was part of the Kauditan District. Fishing entrepreneurs working on the Sulawesi Sea have been interested in Bitung since the 1940s, comparing it to Kema (in the current North Minahasa Regency), which used to be a commercial port, since Bitung, in their opinion, was more strategic and could be utilized as a replacement port for Kema. Based on Government Regulation Number 4 of 1975, dated April 10, 1975, Bitung was inaugurated as the first Administrative City in Indonesia, in conjunction with the growth of Bitung as a strategic area and the fast-rising population. Geographically, Bitung City is located between $1^{\circ} 23^{\prime}$ $23^{\prime \prime}-1^{\circ} 35^{\prime} 39^{\prime \prime}$ North Latitude and $125^{\circ} 1^{\prime} 43^{\prime \prime}-125^{\circ} 18^{\prime}$ 13" East Longitude and has a land area of $304 \mathrm{~km}^{2}$.

The boundaries of Bitung City are:

North: North Minahasa Regency

South: Maluku Sea

West: North Minahasa Regency

East: Maluku Sea

\section{Overview of the Port}

1) Definition of Port:

A port is a location comprising of land and surrounding waterways within defined boundaries that are used for government and economic activities such as ship docking, docking, up and down passengers, loading and unloading of commodities, and port support activities, as 
well as a place of movement for ships. Intra and intermode transportation (PP RI No. 70 of 1996 concerning ports, Ministry of Transportation RI, page 2) and According to Bambang Triatmodjo, ports are airports equipped with buildings for passenger and cargo services such as piers, moorings, and all their equipment (Triadmodjo, 1996).

Ports have several classification methods, namely:

a) Classification from a technical point of view:

- Natural harbor

The port that occurs from geographical conditions is an area that juts into (in the form of a bay).

- Artificial Port

An area of water created by humans in such a way that it is protected against natural disturbances originating from the sea.

b) Classification in terms of services:

- Operated port

Ports that are under government guidance that are adapted to their conditions, potential, and development capabilities.

- Autonomous Port

Ports that are authorized to regulate themselves in accordance with established rules.

- Uncultivated ports

It is a port for people's shipping such as fishing areas and others.

c) Classification by type of trade

- Seaports

Ports that are open to foreign and domestic trade

- Beach Harbor

Ports that are open to domestic trade.

d) Classification of ship types and their cargo

- Main Port

It is a sending and collecting port that serves large ships.

- Port of Caban (feeder)

It is a collecting port for the main port serving medium ships and the surrounding area is a potential industrial area

- Ferry Port

The actual port is a ferry port but there are also traditional cargo activities.

(Soedjono, 2002)

Port facilities are divided into two, namely:

a) The main port facilities include:

- Waters of anchorage

- Anchored pools

- Transfer between ships

- Pier

- Passenger terminal

- Warehousing

- Stacking field

- Container terminals

- Offices for government activities and services
- Bunker facilities

- Water, electricity, and telecommunications installations

- Road network and railway tracks

- Firefighting facilities

- Motorized vehicle waiting area

b) Port support facilities include

- Office area for port service users

- Public facilities

- Waste storage area

- Tourism, postal, and telecommunications facilities

- Hospitality and restaurant facilities

- Port development area

- Trading area

- Industrial area

\section{RESULTS AND DISCUSSION}

A. Bitung Port

Bitung Harbor has the following piers:

- Ocean Pier, 607 meters long with a depth of about 5 meters.

- Nusantara Pier, 652 meters long with a depth of about 6 meters.

- Pier for the container.

- Pier VIII is $182 \mathrm{~m}$ long, $20 \mathrm{~m}$ deep.

- Pier IX, 60 m long, $10 \mathrm{~m}$ deep.

In addition, there are other facilities that support the operation of the port, namely:

- Incorporation Facility (to assist in anchoring)

- Equipment for handling

i. Container Crane (CC) with SWL 26.5 tons (1 unit)

ii. Transtainers with capacity of 36.5 tons ( 2 units)

iii. Reach Staker with capacity of 42 tons (1 unit)

iv. Reach Staker with capacity of 45 tons (1 unit)

v. Head Truck with capacity of 24 tons (5 units)

vi. Chassis 40 feet long, with capacity of 36 tons (4 units)

vii. Chassis 20 feet long, with capacity of 24 tons (4 units)

viii. Forklift with capacity of 5 tons ( 1 unit)

ix. Forklift with capacity of 2 tons ( 2 units)

x. Forklift Battery with capacity of 2 tons (2 units)

xi. Tronton with capacity of 10 tons (2 units)

xii. Mobile Crane with capacity of 35 tons (1 unit)

- Clean Water (capacity for supply is around 100 to 150 tons/hour)

- Refueling (diesel oil and marine fuel only, provided by PERTAMINA).

- Dry Pier for repairs (heling wharf under 100 tons)

- Warehouse

- Immigration

- Medical Facilities (Doctor Port) 


\section{PORT OF BITUNG}

Year 2014:

Installed Capacity: 300.000 Teus/Year

Volume (throughtput) : 200.000 Teus

Average Growth per year, 2010-2014 =14\%

Projected growth per year, 2015-2019=10\%

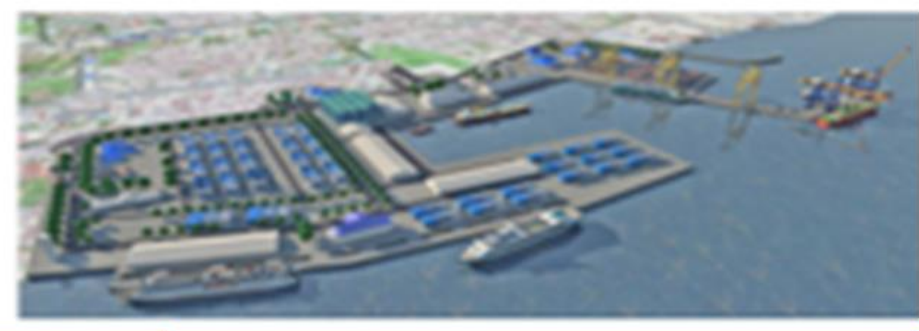

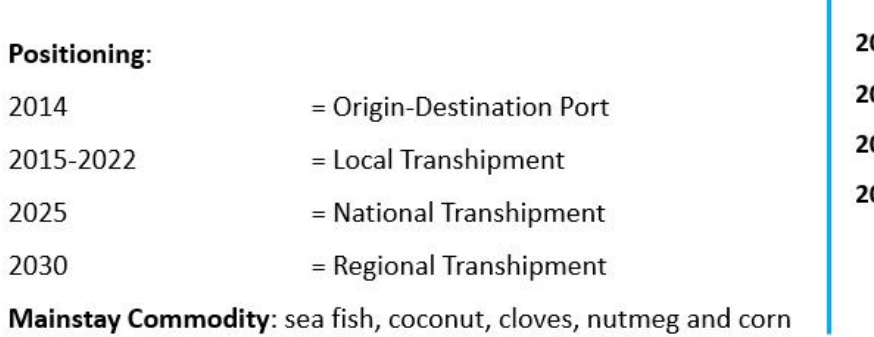
2015
: The implementation of the revitalization of Bitung Port
2015-2022 : Cap/yr
$: 1$ mil Teus
2025
: Capt/Yr
$: 1.5$ mil Teus
2030

: Cap/Yr

Figure. 1. Bitung Port

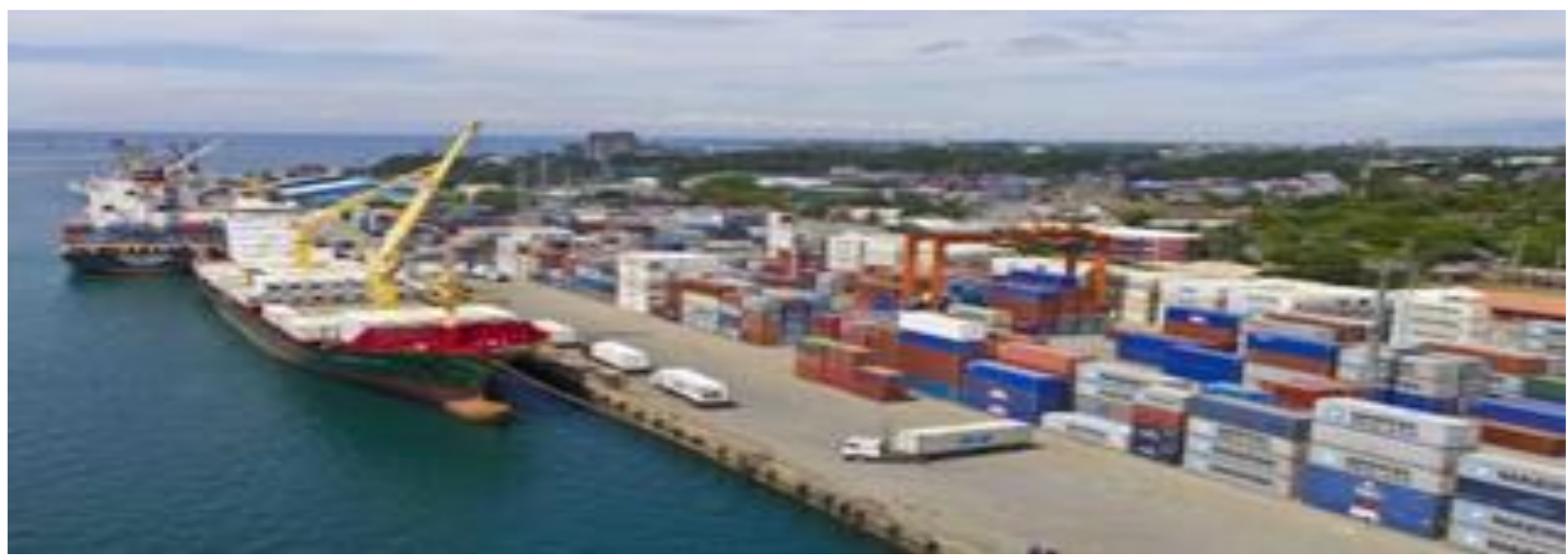

Figure. 2. Davao Port.

\section{B. Davao Port}

The Port of Davao (Filipino: daungan dabaw ng, Cebuano: pantalan sa dabaw) is a port in the Philippine island of Mindanao. Davao Harbor is made up of a multitude of ports that are all located inside Davao Bay, a bay in the Sulawesi Sea that is based in Brgy Sasa, Davao City. Container cargo, raw material export, bulk cargo, general cargo, and passenger traffic facilities are the mainstays of Davao's port.

Apart from Manila, Subic, Cebu, and Zamboanga, Davao Port is one of the major ports. The port of Davao, also known as the Davao district port, encompasses Davao City, which navigates the four provinces mentioned above. Davao is used for port services and international commerce in addition to transiting between islands. On the shores of Davao Bay, 974 kilometers south of Manila, sits the city of Davao. Del Norte, Davao del Sur, West Davao, and Davao Oriental are the four districts that make up Davao. Davao City is administratively autonomous from Davao del Sur, but solely in a political sense. The harbor is accessible via Davao Bay in Davao City, which has two entrances. The first is in the Pakiputan Strait, which connects Davao with the waters west of Samal Island. The other lies to the east of Samal Island, which is primarily utilized as an exit for ships departing from Davao Bay's northern end.
Normally, international ships stopped in Davao at the port of Sasa, Davao are handled. In a week, roughly 3040 ships dock at this port, with the majority of the ships being international. The majority of them are container ships with a length of more than 200 meters that are gearless. Fresh fruits, primarily Cavendish bananas, as well as other fruits such as papaya, mango, pineapple, and fresh vegetable items (such as asparagus and lettuce) are typically exported from Davao.

\section{Crossing Davao-Bitung}

The inaugural voyage of the Ro-Ro ship route DavaoGeneral Santos Philippines - Bitung Indonesia is a manifestation of the Signing of the Joint Declaration on Sea Connectivity Indonesia - the Philippines which was carried out on April 28, 2017, and was officially launched on April 30, 2017, in Manila, the Philippines, witnessed by the President of the Republic of Indonesia Joko Widodo and the President of the Philippines Rodrigo Duterte.

This is a manifestation of the result of the signing of the Indonesia-Philippine Joint Declaration which is a follow-up to the BIMP-EAGA Sea Linkages Working Group meeting in Manado on 19-20 April 2017, which was attended by representatives from BIMP EAGA 
member countries Brunei Darussalam, Indonesia, Malaysia, and the Philippines as well as representatives from the BIMP Facilitation Center (FC), BIMP EAGA Business Council (BEBC) and the Asian Development (ADB). The realization of Indonesia-Philippine's sea connectivity is also in line with the vision of the Government of Indonesia under the leadership of President Joko Widodo and Vice President Jusuf Kalla, which is to restore Indonesia's maritime glory which can be achieved by developing the maritime sector, including maritime stakeholders to produce maritime independence.

Previously, at the launch of the maiden voyage of the MV. Super Shutle Roro 12 at Kudos Port, Davao Philippines, Minister of Transportation of the Republic of Indonesia Budi Karya Sumadi said that the shipping service is expected to be optimally utilized in advancing sub-regions both in terms of connectivity, trade, people to people contact between Indonesia - Philippines and ASEAN.

This ship is operated by Asian Marine Transport Corp., a company from the Philippines and can carry containers of 20' to 500 pieces. The Davao Bitung trip will only take 1.5 days faster than the previous route, namely from Manila to Jakarta then to Bitung which takes 3-5 weeks. The opening of direct shipping lanes using Ro/Ro ships for the Philippines-Indonesia route or the Davao-Bitung port has triggered port SOEs to improve services through efficient domestic routes. President Director of PT Pelindo IV (Persero), Doso Agung said, Pelindo IV as a state-owned company with a port-managed area in Eastern Indonesia (KTI) will continue to boost domestic direct shipping without having to stop over to Java Island.

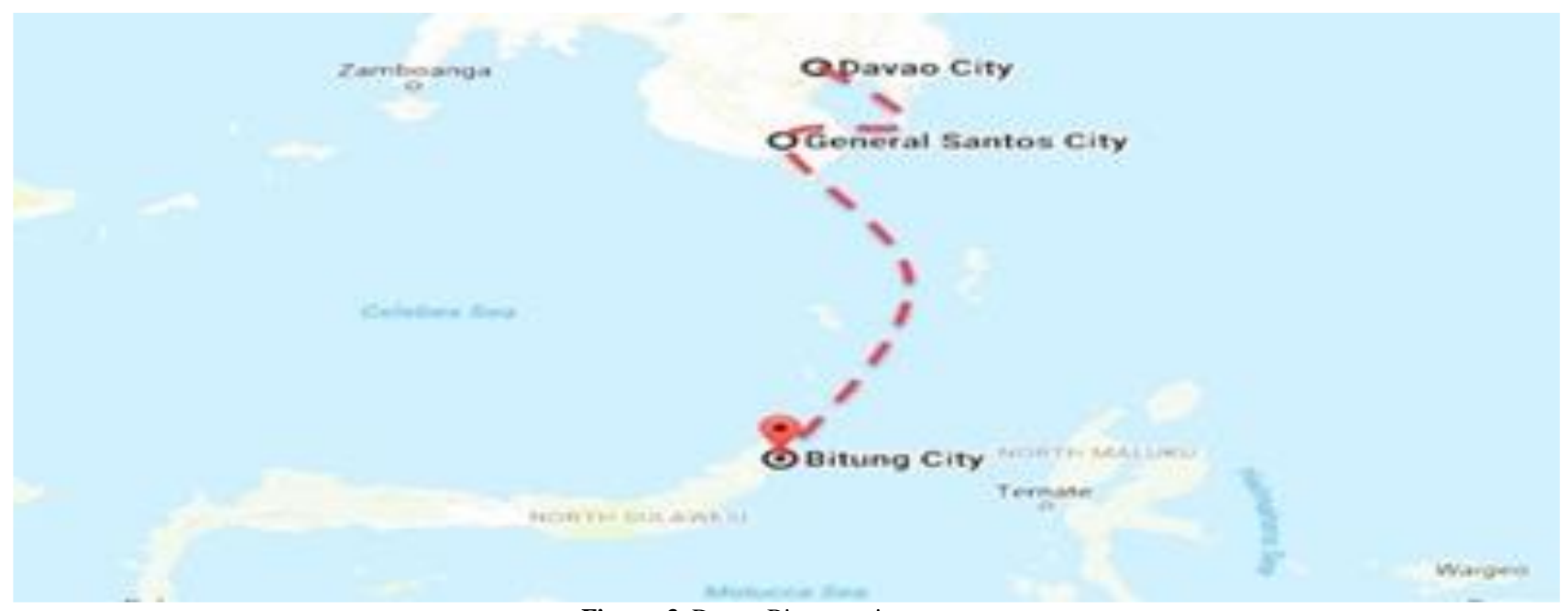

Figure. 3. Davao-Bitung cruise route

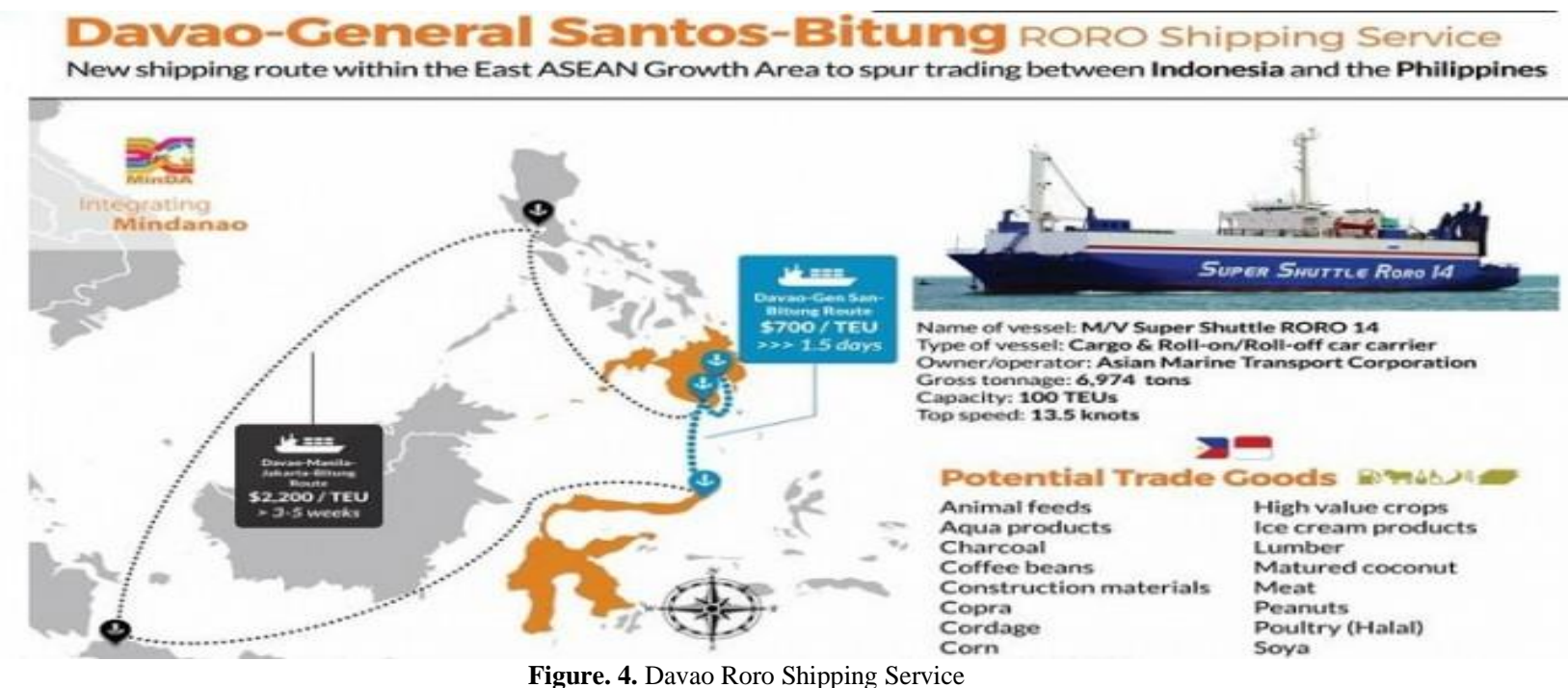

\section{CONCLUSION}

From this research, it can be concluded:

1) The city of Bitung in general and the port of Bitung, in particular, have international standard physical facilities and facilities, mastery of technology, and the closest distance to the Philippines via Davao by using
Ro/Ro ferries as their strengths so that their use can be optimized to increase the number of passengers and also especially export commodity goods that can be served so that it will increase regional income.

2) MV ship. Super Shutle Roro 12 is operated by Asian Marine Transport Corp., a company from the Philippines and can transport 20' to 500 sized containers. However, 
because the ship that sailed from Davao to Bitung only sailed once and did not return, so it could not be analyzed further about the ship.

3) Bitung port has proper facilities as ferry terminals and international freight transport which have separated the departure and arrival of passengers and also have fairly good security procedures.

4) Sasa Port in Davao City Philippines is a port that mostly transports containers that usually consist of fresh fruits and vegetables for international routes.

\section{REFERENCES}

[1] Frinston Lim@inquirer.net: New ferry service from Davao City to Indonesia to boost EAGA trade: https://globalnation.inquirer.net/155548/new-ferry-service-davaocity-indonesia-boost-eaga-trade\#ixzz57nAjQk2p

[2] Kramadibrata, Soedjono: Port Planning, ITB, Bandung, 2002.

[3] Pelindo 4: Bitung Container Terminal.

[4] Government Regulation no. 61 of 2009 concerning Ports.

[5] Triadmodjo, Bambang: Port, Beta Offset, 1996, page 13

[6] RI Law Number 44 of 2007

[7] https://ekbis.sindonews.com/read/1202144/34/jalur-roro-davaobitung-dibuka-picu-pelayaran-langsung-domestik-1493804591

[8] http://beritatrans.com/2017/05/02/kemhub-sambut-kedatanganperdana-kapal-ro-ro-rute-davao-bitung/ 